\title{
Induction and growth pattern of callus from Piper permucronatum leaves
}

\author{
SANTOS, M.R.A. ${ }^{*}$; GUIMARÃES, M.C.M.2; PAZ, E.S.2; MAGALHÃES, G.M.O.2; SOUZA, C.A. ${ }^{2}$; SMOZINSKI, \\ C.V. $;$; NOGUEIRA, W.O. ${ }^{2}$ \\ 'Embrapa Rondônia, BR 364, km 5,5, C.P.127, Porto Velho-RO, 76815-800. ${ }^{2}$ Universidade Federal de Rondônia, \\ BR 364, km 9,5, Porto Velho-RO, 76801-059. *Autor para correspondência: mauricio.santos@embrapa.br
}

\begin{abstract}
Piper permucronatum is a perennial shrub, a medicinal plant native to the Amazon Rainforest. Traditionally, the tea of its leaves is used to combat menstrual and intestinal cramps, stomach pain, digestive problems, diarrhea, hemorrhage, and nausea. Its leaf's essential oil is effective against Aedes aegypti larvae; its flavones and flavanones have a fungicidal effect against Clamidosporium cladosporioides and C. sphaerospermum; its hexanic extract is effective against Leishmania amazonensis. The objective of this study was to provide a protocol for callus induction from $P$. permucronatum leaves and an identification of the callus growth pattern, focusing on the deceleration phase, when the callus cells must be subcultured into liquid medium in order to produce a cell suspension cultures. Leaf explants were inoculated in a solid MS medium supplemented with factorial combinations of 2,4-D, BA, NAA and $\mathrm{GA}_{3}$. Callus formation was evaluated weekly until the $4^{\text {th }}$ day. Subsequently, new explants were inoculated at the hormonal combination that resulted in the highest callus cell proliferation and, every seven days during a period of 70 days, samples were dried and weighed to determine the callus growth pattern. NAA and $\mathrm{GA}_{3}$ were not effective for callus induction. Combinations of 2,4-D and BA resulted in callus induction and proliferation. The highest percentage of callus induction was observed with the combination of $4.52 \mu \mathrm{M} 2,4-\mathrm{D}$ and $4.44 \mu \mathrm{M}$ BA. The calluses thereby produced were friable and whitish. The callus growth pattern followed a sigmoid shape. The deceleration phase started on the $56^{\text {th }}$ day of culture.
\end{abstract}

Keywords: Piperaceae, growth regulators, callogenesis.

RESUMO: Indução e padrão de crescimento de calos de folhas de Piper permucronatum. Indução e padrão de crescimento de calos de folhas de Piper permucronatum. Piper permucronatum é um arbusto perene, uma planta medicinal native da Floresta Amazônica. Tradicionalmente, o chá de suas folhas é usado em casos de cólicas menstruais e intestinais, dores de estômago, problemas digestivos, diarreia, hemorragia e náusea. O óleo essencial das folhas é efetivo contra a larva de Aedes aegypti; suas flavonas e flavanonas têm efeito fungicida contra Clamidosporium cladosporioides e C. sphaerospermum; seu extrato hexânico é efetivo contra Leishmania amazonensis. O objetivo deste trabalho foi determinar um protocolo para indução de calos em folhas de $P$. permucronatum e identificar o padrão de crescimento dos calos, com foco na fase de desaceleração, quando as células de calo devem ser subcultivadas em meio líquido para produzir culturas de células em suspensão. Explantes foliares foram inoculados em meio MS sólido suplementado com combinações fatoriais de 2,4-D, BAP, ANA e $\mathrm{GA}_{3}$. A formação de calos foi avaliada semanalmente até o $49^{\circ}$ dia. Posteriormente, novos explantes foram inoculados na combinação hormonal que resultou na maior proliferação de células de calo e, a cada sete dias durante 70 dias, amostras foram secas e pesadas para determinar o padrão de crescimento dos calos. ANA e $\mathrm{GA}_{3}$ não foram efetivas para a indução de calos. Combinações de 2,4-D e BAP resultaram em indução e proliferação de calos. A maior porcentagem de indução de calos foi observada com a combinação de 4,52 $\mu \mathrm{M}$ de 2,4-D e 4,44 $\mu \mathrm{M}$ de BAP. Os calos produzidos eram friáveis e esbranquiçados. O crescimento dos calos seguiu um padrão sigmoide. A fase de desaceleração iniciou no $56^{\circ}$ dia de cultivo.

Palavras-chave: Piperaceae, reguladores de crescimento, calogênese. 


\section{INTRODUCTION}

Nature has developed an enormous diversity of species during several billion years of evolution and all these species coexist in ecosystems and interact with each other in several ways in which chemistry plays a major role (Verpoorte, 1998). It is well established that secondary metabolites play an important role in plant chemical defense (Morais et al., 2007), besides those attractants that promote pollination and seed dispersal (Vanin et al., 2008).

Several species of the Piper genus are native to the Amazon Rainforest and are notable producers of chemical compounds which have several biological effects in insects, fungi, bacteria, Trypanossoma cruzi (Navickiene et al., 2003; Dyer et al., 2004; Danelutte et al., 2005; Balbuena et al., 2009) and can also affect human health, as analgesic, anti-depressant, cytoprotective, anti-ulcer, anticonvulsant, anti-inflammatory, and antioxidant agents (Ahmad et al., 2010).

Piper permucronatum Yuncker is a perennial shrub, a medicinal plant native to the Amazon Rainforest. Traditionally, the tea of its leaves is used to combat menstrual and intestinal cramps, stomach pain, digestive problems, diarrhea, hemorrhage, and nausea (Anjos Júnior, 2007). The bioactivity of the species has been demonstrated; its leaf's essential oil (dilapiol, myristicin, elemicine, and asaricine) is effective against Aedes aegypti larvae (Morais et al., 2007); its flavones and flavanones have a fungicidal effect against Clamidosporium cladosporioides and C. sphaerospermum (Lemeszenski, 2013); its hexanic extract is effective against Leishmania amazonensis and Artemia salina (Anjos Júnior, 2007). Sesquiterpenes and monoterpenes have also been identified (Torquilho et al., 1999).

The effects of $P$. permucronatum compounds in diverse organisms indicate their potential to be used as replacement for, or simultaneously with, agrochemicals for the control of pests and diseases. The reduction in the use of agrochemicals is a current and topical challenge, considering the toxicity of these products for the environment, the demand for healthy food, and the development of resistance to fungicides and insecticides (Khan et al., 2011, Speck-Planche et al., 2011).

Biotechnological approaches, more specifically plant tissue cultures, have potential as a supplement to traditional agriculture in the industrial production of bioactive plant metabolites (Rao \& Ravishankar, 2002). Cell suspension culture systems are used for large scale culturing of plant cells from which secondary metabolites are extracted. The advantage of this method is that it can ultimately provide a continuous, reliable source of natural products, which can be produced at a rate similar or superior to that of intact plants (Vanisree et al., 2004). These cultures offer the possibility of obtaining desirable amounts of compounds as well as ensuring sustainable conservation and rational utilization of biodiversity (Coste et al., 2011). Besides, in vitro production of secondary compounds under controlled conditions prevents fluctuations in concentrations due to geographical, seasonal, and environmental variations (Murthy et al., 2014).

This research is part of a project in which in vitro produced secondary metabolites from Piper species will be tested against agricultural pests and diseases. As such, the study provides a protocol for callus induction from $P$. permucronatum leaves and an identification of the callus growth pattern, focusing on the stationary phase, when the callus cells must be subcultured into liquid medium in order to produce a cell suspension culture.

\section{MATERIALS AND METHODS}

Plant materials and sterilization.

Young leaves were excised from flowering, healthy, and disease free Piper permucronatum Yuncker Piperaceae (traditional name: elixir paregórico) stock plants from Embrapa (Brazilian Agricultural Research Corporation), in Porto Velho, RO, Brazil. Taxonomic identification was carried out at the herbarium of INPA (National Institute of Amazon Researches) by Dr. J. Gomes, Voucher Number 211711 , by using branches with leaves and flowers collected in January 2005 in Porto Velho, Rondonia State, Brazil. The plants were six months old and approximately $90 \mathrm{~cm}$ tall, maintained in a shaded greenhouse under a maximum photosynthetic photon flux density of $300 \mu \mathrm{mol} . \mathrm{m}^{-2} \cdot \mathrm{s}^{-1}$ and average temperature of $25.6^{\circ} \mathrm{C}$. After washing with running tap water and a detergent agent for five minutes, the leaves were surface-sterilized in $70 \%(\mathrm{v} / \mathrm{v})$ ethanol for 1 minute and soaked in a $1.0 \%(\mathrm{v} / \mathrm{v})$ sodium hypochlorite solution for 1 minute, and then rinsed three times with sterile water. Explants were produced by cutting the leaves into $1 \mathrm{~cm}^{2}$ pieces in sterile petri dishes.

Callus induction and growth. Leaf explants were individually transferred with the adaxial surface up, to test tubes $(25 \mathrm{~mm} \times 150 \mathrm{~mm}$ ) containing 10 $\mathrm{mL}$ of an MS (Murashige \& Skoog, 1962) basal culture medium supplemented with $3 \%(\mathrm{w} / \mathrm{v})$ sucrose, $0.6 \%(\mathrm{w} / \mathrm{v})$ agar and factorial combinations of 2,4-Dichlorophenoxyacetic acid (2,4-D) (0, 4.52, 9.05 , or $18.10 \mu \mathrm{M})$ and 6-Benzylaminopurine (BA) $(0,4.44,8.88$, or $17.76 \mu \mathrm{M})$; 2,4-D $(0,0.45,0.91$, or $1.81 \mu \mathrm{M})$ and $\mathrm{BA}(0$ or $0.89 \mu \mathrm{M})$; 2,4-D $(0,0.45$, 0.91 , or $1.81 \mu \mathrm{M})$ and Gibberellic acid $\left(\mathrm{GA}_{3}\right)(0$ or $1,44 \mu \mathrm{M}) ; \mathrm{BA}(0$ or $0.89 \mu \mathrm{M})$ and Naphthaleneacetic acid (NAA) $(0$ or $5.37 \mu \mathrm{M})$, totaling 36 treatments

Rev. Bras. PI. Med., Campinas, v.18, n.1, p.142-148, 2016. 
(Table 1) each one with three replicates of three explants. The growth regulators, their concentrations and combinations tested were based on successful studies on callus induction in Piper species; $P$. cernuum, P. crassinervum (Danelutte et al., 2005), $P$. solmsianum (Balbuena et al., 2009), P. aduncum (Delgado-Paredes et al., 2013), and P. hispidinervum (Santiago, 2013). The $\mathrm{pH}$ of the medium was adjusted to 5.8 before the addition of agar followed by autoclaving at $121^{\circ} \mathrm{C}$ for 20 minutes.

The percentage of explants where callogenesis occurred was evaluated weekly until the $49^{\text {th }}$ day, when all the explants were dried at $50^{\circ} \mathrm{C}$ for 24 hours and subsequently weighed to quantify callus cell proliferation where it occurred. After that, new explants were inoculated at the hormonal combination that resulted in the highest callus cell proliferation at the same conditions described and, every seven days during a period of 70 days, three samples were dried and weighed to determine the callus growth pattern.

Experimental design and evaluation. All the cultures were incubated in a growth chamber at $25 \pm 2^{\circ} \mathrm{C}$ under light provided by cool white fluorescent

TABLE 1. Factorial combinations of growth regulators supplemented to an MS medium before inoculation of P. permucronatum leaf explants.

\begin{tabular}{|c|c|c|c|c|}
\hline \multirow[b]{2}{*}{ Treatments } & \multicolumn{4}{|c|}{ Growth Regulators $(\mu \mathrm{M})$} \\
\hline & $2,4-D$ & BA & $\mathrm{GA}_{3}$ & NAA \\
\hline 1 & - & - & - & - \\
\hline 2 & - & 4.44 & - & - \\
\hline 3 & - & 8.88 & - & - \\
\hline 4 & - & 17.76 & - & - \\
\hline 5 & 4.52 & - & - & - \\
\hline 6 & 4.52 & 4.44 & - & - \\
\hline 7 & 4.52 & 8.88 & - & - \\
\hline 8 & 4.52 & 17.76 & - & - \\
\hline 9 & 9.05 & - & - & - \\
\hline 10 & 9.05 & 4.44 & - & - \\
\hline 11 & 9.05 & 8.88 & - & - \\
\hline 12 & 9.05 & 17.76 & - & - \\
\hline 13 & 18.10 & - & - & - \\
\hline 14 & 18.10 & 4.44 & - & - \\
\hline 15 & 18.10 & 8.88 & - & - \\
\hline 16 & 18.10 & 17.76 & - & - \\
\hline 17 & - & - & - & - \\
\hline 18 & - & 0.89 & - & - \\
\hline 19 & 0.45 & - & - & - \\
\hline 20 & 0.45 & 0.89 & - & - \\
\hline 21 & 0.91 & - & - & - \\
\hline 22 & 0.91 & 0.89 & - & - \\
\hline 23 & 1.81 & - & - & - \\
\hline 24 & 1.81 & 0.89 & - & - \\
\hline 25 & - & - & - & - \\
\hline 26 & - & - & 1.44 & - \\
\hline 27 & 0.45 & - & - & - \\
\hline 28 & 0.45 & - & 1.44 & - \\
\hline 29 & 0.91 & - & - & - \\
\hline 30 & 0.91 & - & 1.44 & - \\
\hline 31 & 1.81 & - & - & - \\
\hline 32 & 1.81 & - & 1.44 & - \\
\hline 33 & - & - & - & - \\
\hline 34 & - & - & - & 5.37 \\
\hline 35 & - & 0.89 & - & - \\
\hline 36 & - & 0.89 & - & 5.37 \\
\hline
\end{tabular}


tubes $\left(50 \mu \mathrm{mol} . \mathrm{m}^{-2} \cdot \mathrm{s}^{-1}\right)$. Treatments were arranged in a completely randomized design. By using the Genes statistical program, averages of numbers of callus per explant and callus dry weights were compared by Tukey's test $(P \leq 0.05)$, callus and suspension growth data were submitted to regression analysis (Pimentel-Gomes, 2009).

\section{RESULTS}

Callus induction. The factorial combinations between NAA ( 0 or $5.37 \mu \mathrm{M})$ and BA $(0$ or $0.89 \mu \mathrm{M})$; $2,4-\mathrm{D}(0,0.45,0.90$, or $1.81 \mu \mathrm{M})$ and $\mathrm{GA}_{3}(0$ or 1,44 $\mu \mathrm{M})$; $2,4-\mathrm{D}(0,0.45,0.91$, or $1.81 \mu \mathrm{M})$ and $\mathrm{BA}(0$ or $0.89 \mu \mathrm{M})$ did not result in callus induction on the leaf explants or the induction was not followed by a relevant proliferation of callus cells. The combination of 2,4-D $(0,4.52,9.05$, or $18.10 \mu \mathrm{M})$ and $\mathrm{BA}(0,4.44$, 8.88 , or $17.76 \mu \mathrm{M})$ resulted in callus induction and proliferation in all the treatments supplemented with 2,4-D (Table 2). The highest percentage of callus induction was observed with the combination of 4.52 $\mu \mathrm{M} 2,4-\mathrm{D}$ and $4.44 \mu \mathrm{M}$ BA. The calluses thereby produced were friable and whitish.

Callus growth. The growth pattern of $P$. permucronatum callus followed a sigmoid shape (Figure 1). It was possible to identify a lag phase from the day of inoculation until the $21^{\text {st }}$ day, an exponential phase from the $21^{\text {st }}$ to the $49^{\text {th }}$ day, a linear phase from the $49^{\text {th }}$ to the $56^{\text {th }}$ day, a deceleration phase from the $56^{\text {th }}$ to the $63^{\text {rd }}$ day, and a decline phase from the $63^{\text {rd }}$ to the $70^{\text {th }}$ day.

\section{DISCUSSION \\ Callus induction}

There is a great variation of in vitro responses among Piper species. In the present research it was observed that NAA, isolated or in combination with $B A$, was not efficient for callus induction in leaf explants of $P$. permucronatum. Differently, DelgadoParedes et al. (2013) observed callus induction in leaf explants of both $P$. cernuum and $P$. aduncum in MS medium supplemented with a combination of 5.37 $\mu \mathrm{M}$ NAA and $0.89 \mu \mathrm{M}$ BA. This combination was tested in this study, but did not result in callus induction.

Santiago (2003) evaluated the effect of combinations of 2,4-D, BA, and NAA in MS medium to induce callus in leaf explants of $P$. hispidinervium and observed the highest percentage of friable green callus, $98.3 \%$, with the combination of 27.14 $\mu \mathrm{M}$ 2,4-D, 8.88 $\mu \mathrm{M}$ BA, and 2.69 $\mu \mathrm{M}$ NAA. Different results were found by Valle (2003), who observed that higher concentrations of these growth regulators were effective for callus induction in leaf explants of $P$. hispidinervium, with a pro-cytokinin hormonal balance; the highest callus formation was achieved in MS medium supplemented with $22.62 \mu \mathrm{M} 2,4-\mathrm{D}$ and $45.29 \mu \mathrm{M}$ BA, or $26.85 \mu \mathrm{M}$ NAA and $45.29 \mu \mathrm{M}$ BA.

The use of 2,4-D and $\mathrm{GA}_{3}$ together did not promote callus induction in $P$. permucronatum leaf explants. Danelutte et al. (2005), aiming at the establishment of cell suspensions from leaves of $P$. crassinervium and $P$. cernuum, found the highest callus induction by using MS medium supplemented with $0.11 \mu \mathrm{M}$ Indoleacetic acid (IAA) and $0.06 \mu \mathrm{M}$ $\mathrm{GA}_{3}$ in $P$. crassinervium and $0.91 \mu \mathrm{M} 2,4-\mathrm{D}$ and 1.44 $\mu \mathrm{M} \mathrm{GA}$ in $P$. cernuum. The last combination was also tested in the current approach, without success.

Lower concentrations of 2,4-D (0.45, 0.91 , and $1.81 \mu \mathrm{M}$ ) were not efficient in this study. Contrastingly, Delgado-Paredes et al. (2013) observed callus induction in leaf explants of both $P$. cernuum and $P$. aduncum in MS medium supplemented with $0.91 \mu \mathrm{M} 2,4-\mathrm{D}$. Also using lower concentrations of 2,4-D, Balbuena et al. (2009), aiming at the establishment of cell suspension culture of $P$. solmsianum, evaluated the induction of callus in leaf and petiole explants cultivated in an MS medium supplemented with combinations of 2,4-D, BA, NAA, and IAA. The authors observed that the highest proliferation of callus cells occurred in the combination of $0.91 \mu \mathrm{M} 2,4-\mathrm{D}$ and $8.88 \mu \mathrm{M}$ BA, for both explants.

Dominguez et al. (2006) used combinations of IAA with NAA or 2,4-D with Kinetin (Kin) in an MS medium to promote callus induction in $P$. auritum leaves aiming at the subsequent regeneration of plantlets from the calluses. They observed that

TABLE 2. Percentages of callus induction in leaf explants of $P$. permucronatum in an MS medium supplemented with $B A$ and 2,4-D, 49 days after inoculation.

\begin{tabular}{cccc}
\hline & & $2,4-\mathrm{D}(\mu \mathrm{M})$ & \\
\cline { 2 - 4 } $\operatorname{BAP}(\mu \mathrm{M})$ & 4.52 & 9.05 & $60 \mathrm{Aa}$ \\
\hline- & $40 \mathrm{Bc}^{*}$ & $45 \mathrm{Bc}$ & $75 \mathrm{Ba}$ \\
4.44 & $100 \mathrm{Aa}$ & $80 \mathrm{Ba}$ & $70 \mathrm{Aa}$ \\
8.88 & $65 \mathrm{Ab}$ & $60 \mathrm{Ab}$ & $60 \mathrm{Aa}$ \\
17.76 & $50 \mathrm{Ac}$ & $60 \mathrm{Ab}$ \\
\hline
\end{tabular}

*Means followed by the same capital letter in the rows or small letter in the columns do not differ significantly at $5 \%$ probability by Tukey's test. 


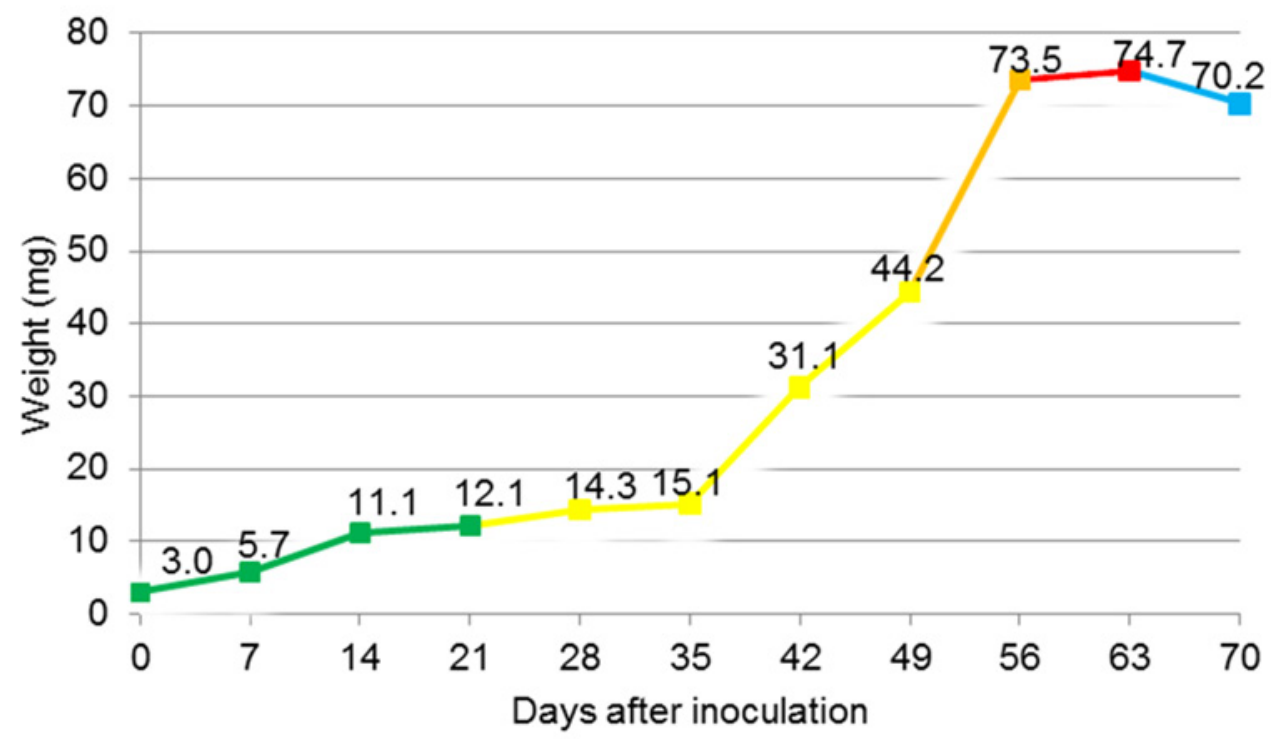

FIGURE 1. Growth pattern of Piper permucronatum calluses cultivated in an MS medium supplemented with $4.52 \mu \mathrm{M} 2,4-\mathrm{D}$ and $4.44 \mu \mathrm{M}$ BA, with the lag (green), exponential (yellow), linear (orange), deceleration (red), and decline (blue) phases.

media containing IAA and NAA resulted in softer watery calluses, which turned brown later; the highest percentage of callus induction was $72 \%$, achieved with $2.26 \mu \mathrm{M} 2,4-\mathrm{D}$ and $6.97 \mu \mathrm{M}$ Kin. Delgado-Paredes et al. (2012) observed callus covering two thirds of leaf explants of $P$. aduncum by supplementing an $\mathrm{MS}$ medium with a combination of NAA $(0.11 \mu \mathrm{M}), \mathrm{BA}(0.22 \mu \mathrm{M})$, and $\mathrm{GA}_{3}(0.06 \mu \mathrm{M})$.

The necessity of 2,4-D to induce callus in $P$. permucronatum was clear; leaf explants were not responsive to $\mathrm{BA}$ alone, at the concentrations of $4.44,8.88$, and $17.76 \mu \mathrm{M}$. The opposite was observed by Kelkar et al. (1996), who reached 90, 75,75 , and $67 \%$ of callus induction in $P$. colubrinum leaf explants, utilizing 2.22, 4.44, 8.88 and $13.32 \mu \mathrm{M}$ BA, respectively.

In the present research the use together of 2,4-D $(4.52,9.05$, and $18.10 \mu \mathrm{M})$ and $\mathrm{BA}(4.44,8.88$, and $17.76 \mu \mathrm{M})$ at relatively higher concentrations was, in general, adequate to promote callus induction in leaf explants of $P$. permucronatum, reaching $100 \%$ with $4.52 \mu \mathrm{M} 2,4-\mathrm{D}$ and $4.44 \mu \mathrm{M}$ BA. Similarly, Kelkar et al. (1996) observed that the combination of 2.22 $\mu \mathrm{M}$ BA with $2.26 \mu \mathrm{M} 2,4-\mathrm{D}$ resulted in $100 \%$ callus induction in $P$. colubrinum.

Ahmad et al. (2010) also tested 2,4-D, BA, $\mathrm{GA}_{3}$ and NAA in the induction of callus in $P$. nigrum leaves in order to regenerate plantlets from the calluses. The authors found the highest callogenic response in explants cultured on MS medium supplemented with either $2.22 \mu \mathrm{M}$ BA or $4.44 \mu \mathrm{M}$ BA in combination with $5.37 \mu \mathrm{M} N A A$, resulting in 93 and $90 \%$ of callogenesis, respectively. $\mathrm{GA}_{3}$ alone did not result in relevant callus induction, as observed in the present study. However, in combination with BA, GA enhanced the callogenesis to relatively high levels. According to Li et al. (2012) only auxins and not cytokinins induce callogenesis by initiating explant cell dedifferentiation through auxin-responsive gene activation, while cytokinins wold be more related to differentiation, by stimulating the division of the newly formed meristematic cells. All the diverse responses found among Piperspecies in relation to the adequate hormonal balance needed for callus induction can be attributed to the interaction of growth regulators added to the medium with dissimilar endogenous levels of auxins and cytokinins preexistent in the tissues. As stated by Jiménez (2001), very little is known about the possible interactions of an endogenous phytohormone system with the exogenous growth regulators supplied to the nutrient medium; it seems probable that the observed responses of cell culture systems, after a growth regulator supplement, are related to such interactions. The levels of endogenous hormones are dependent on characteristics such as age of the plant, its physiological and nutritional status, and mainly genotype, for these levels are postulated to be the main difference among genotypes with various grades of competence (Bhaskaran \& Smith, 1990). As was mentioned by George et al. (2008), due to genotypic specificity, media and cultural environment often need to be varied from one genus or species of plant to another and even closely related varieties of plants can differ in their cultural requirements.

\section{Callus growth}

Callus growth curves in general are established to identify the stages or phases of fundamental growth processes, in order to determine 
the exact moment to subculture the calluses into a new medium (Santos et al., 2010). These stages are: 1) lag phase: metabolite mobilization starts and synthesis of proteins and specific metabolites occurs, without cell multiplication; 2) exponential phase: cell division reaches the maximum; 3 ) linear phase: cell division reduces; 4 ) deceleration phase: cell division decreases and cell expansion occurs - this is when the cells have to be transferred to a new culture medium due to the reduction of nutrients, agar dryness and accumulation of toxic substances; 5) stationary phase: no cell division or weight increase occur, but the secondary metabolites accumulation reaches the maximum; and 6) decline phase: loss of weight due to cellular death (Castro et al., 2008; Nogueira et al., 2008; Santos et al., 2010).

In the current approach, the growth pattern of $P$. permucronatum callus followed a typical sigmoid shape with the deceleration phase between the $56^{\text {th }}$ and the $63^{\text {rd }}$ day of culture. Differently, Santiago (2003) studied the callus growth in P. hispidinervium and identified the deceleration phase starting from the $42^{\text {nd }}$ day, from which there was a decrease in the dry mass of the calluses. Valle (2003), studying the callus growth of the same species observed the deceleration phase starting on the $40^{\text {th }}$ day. Balbuena et al. (2009) used callus cells of $P$. solmsianum on the $24^{\text {th }}$ day of culture to initiate cell suspension cultures. The appropriate time to subculture the calluses of $P$. permucronatum in order to establish cell suspension cultures is in the beginning of the deceleration phase, on the $56^{\text {th }}$ day of culture, when the cells have to be transferred to a new culture medium due to the reduction of nutrients, agar dryness and accumulation of toxic substances.

\section{CONCLUSION}

Callus induction in leaf explants of $P$. permucronatum can be achieved in MS medium supplemented with $4.52 \mu \mathrm{M} 2,4-\mathrm{D}$ and $4.44 \mu \mathrm{M} \mathrm{BA}$; callus cells at the $56^{\text {th }}$ day of culture are appropriate to start a cell suspension culture.

\section{ACKNOWLEDGEMENT}

The authors thank PIBIC/CNPq (National Council for Scientific and Technological Development) for providing financial support through the scholarship of Smozinski, C.V. and CAPES (Coordination for the Improvement of Higher Education Personnel) for providing scholarship of Guimarães, M.C.M. and Nogueira, W.O.

\section{REFERENCES}

AHMAD, N.; et al., Efficient regeneration and antioxidant potential in regenerated tissues of Piper nigrum L. Plant Cell, Tissue and Organ Culture, v.102, p.129-134, 2010.

ANJOS JÚNIOR, J.F. Estudo fitoquímico e atividade biológica de Piper permucronatum Yuncker (Piperaceae). 2007. 149p. Dissertação (Mestrado Área de Concentração em Parasitologia) - Universidade Federal de Rondônia, Porto Velho.

BALBUENA, T.S.; et al., In vitro morphogenesis and cell suspension culture establishment in Piper solmsianum C. DC. (Piperaceae). Acta Botanica Brasilica, v.23, n.1, p.274-281, 2009.

BHASKARAN, S.; SMITH, R.H. Regeneration in cereal tissue culture: A review. Crop Science, v. 30, n. 6, p.1328-1337, 1990.

CASTRO, A.H.F.; et al., Curva de crescimento, atividade da fenilalanina amônia-liase e teores de fenóis e taninos totais em calos de Stryphnodendron adstringens (Mart.) Coville (Fabaceae-Mimosoideae). Plant Cell Culture \& Micropropagation, v.4, n.2, p.99-104, 2008.

COSTE, A.; et al., Effects of plant growth regulators and elicitors on production of secondary metabolites in shoot cultures of Hypericum hirsutum and Hypericum maculatum. Plant Cell, Tissue and Organ Culture, v.106, n.2, p.279-288, 2011.

DANELUTTE, A.P.; et al., Divergence of secondary metabolism in cell suspension cultures and differentiated plants of Piper cernuum and $P$. crassinervium. Journal of the Brazilian Chemical Society, v.16, n.6B, p.14251430, 2005.

DELGADO-PAREDES, G.E.; et al., Suspensiones celulares y producción de metabolitos secundários em cultivos in vitro de Piper sp. Boletín Latinoamericano y del Caribe de Plantas Medicinales y Aromáticas, v.12, n.3, p.269-282, 2013.

DELGADO-PAREDES, G.E.; et al., Cultivo de tejidos de Piper sp. (Piperaceae): propagación, organogénesis y conservación de germoplasma in vitro. Revista Colombiana de Biotecnología, v.14, n.2, p.49-60, 2012.

DOMINGUEZ, F.; et al., Tissue culture regeneration of a medicinal plant from Mexico: Piper auritum Kunth. HortScience, v.41, n.1, p.207-209, 2006.

DYER, L.A.; RICHARDS, J.; DODSON, C. Isolation, Synthesis, and Evolutionary Ecology of Piper Amides. In: DYER, L.A.; PALMER, A.D.N. Piper: a model genus for studies of phytochemistry, ecology, and evolution. New York: Kluwer Academic, 2004. p.117-139.

GEORGE, E.F.; HALL, M.A.; KLERK, G-J.D. Adventitious regeneration. In: ___eds.) Plant Propagation by Tissue Culture. $3^{\text {rd }}$ ed. Dordrecht: Springer, 2008. p.355-401.

JIMÉNEZ, V.M. Regulation of in vitro somatic embryogenesis with emphasis on the role of endogenous hormones. Revista Brasileira de Fisiologia Vegetal, v. 13, n. 2, p. 196-223, 2001.

KELKAR, S.M.; et al., In vitro plant regeneration from leaf callus in Piper colubrinum Link. Plant Cell Reports, v.16, p.215-218, 1996.

KHAN, H.A.A.; et al., First report of field evolved resistance

Rev. Bras. PI. Med., Campinas, v.18, n.1, p.142-148, 2016. 
to agrochemicals in dengue mosquito, Aedes albopictus (Diptera: Culicidae), from Pakistan. Parasites \& Vectors, v.146, n.4, p.1-11, 2011.

LEMESZENSKI, G.C.F. Protoflavonóides e meroterpenos de espécies de Piper. 2013. 203p. Tese (Doutorado - Área de Concentração em Química) - Instituto de Química, Universidade de São Paulo, São Paulo.

LI, F.; et al., The effect of 2,4-D and kinetin on dedifferentiation of petiole cells in Arabidopsis thaliana. Biologia Plantarum, v. 56, n. 1, p. 121-125, 2012.

MORAIS, S.M.; et al., Chemical composition and larvicidal activity of essential oils from Piper species. Biochemical Systematics and Ecology, v.35, n.10, p.670-675, 2007.

MURASHIGE, T.; SKOOG, F. A revised medium for rapid growth and bioassays with tobacco tissue cultures. Physiologia Plantarum, v.15, n.3, p.473-497, 1962.

MURTHY, H.N.; et al., Production of secondary metabolites from cell and organ cultures: strategies and approaches for biomass improvement and metabolite accumulation. Plant Cell, Tissue and Organ Culture, v.118, n.1, p.1-16, 2014.

NAVICKIENE, H.M.D.; et al., Quantitative determination of anti-fungal and insecticide amides in adult plants, plantlets and callus from Piper tuberculatum by reverse-phase high-performance liquid chromatography. Phytochemical Analysis, v.14, p.281-284, 2003.

NOGUEIRA, R.C.; et al., Curva de crescimento e análises bioquímicas de calos de murici-pequeno (Byrsonima intermedia A. Juss.). Revista Brasileira de Plantas Medicinais, v.10, n.1, p.44-48, 2008.

PIMENTEL-GOMES, F. Curso de Estatística Experimental. Piracicaba: Fealq, 2009. 451p.

RAO, S.R.; RAVISHANKAR, G.A. Plant cell cultures: chemical factories of secondary metabolites.
Biotechnology Advances, v.20, n.2, p.101-153, 2002. SANTIAGO, E.J.A. Caracterização morfológica e bioquímica de calos de pimenta longa (Piper hispidinervium Candolle, De Candolle). 2003. 162p. Tese (Doutorado - Área de Concentração em Fitotecnia) - Departamento de Fitotecnia, Universidade Federal de Lavras, Lavras.

SANTOS, M.R.A.; et al., Determination of callus growth curve in Conilon coffee. Revista Caatinga, v.23, n.1, p.133-136, 2010.

SPECK-PLANCHE, A.; et al., QSAR model toward the rational design of new agrochemical fungicides with a defined resistance risk using substructural descriptors. Molecular Diversity, v.15, n.4, p.901-909, 2011.

TORQUILHO, H.S.; et al., Essential Oil of Piper permucronatum Yuncker (Piperaceae) from Rio de Janeiro, Brazil. Journal of Essential Oil Research, v.11, n.4, p.429-430, 1999.

VALLE, R.C.S.C. Estratégias de cultivo de células de pimenta longa (Piper hispidinervium) e determinação de parâmetros cinéticos. 2003. 165p. Tese (Doutorado - Área de Concentração em Engenharia Química) Departamento de Engenharia Química, Universidade Federal de Santa Catarina, Florianópolis.

VANIN, S.A.; et al., Insect feeding preferences on Piperaceae species observed in São Paulo city, Brazil. Revista Brasileira de Entomologia, v.52, n.1, p.7277, 2008.

VANISREE, M.; et al., Studies on the production of some important secondary metabolites from medicinal plants by plant tissue cultures. Botanical Bulletin of Academia Sinica, v.45, p.1-22, 2004.

VERPOORTE, R. Exploration of nature's chemodiversity: the role of secondary metabolites as leads in drug development. Drug Discovery Today, v.3, n.5, p.232-238, 1998.

Rev. Bras. PI. Med., Campinas, v.18, n.1, p.142-148, 2016. 